\title{
Hydraulic and Geomorphic Monitoring of Experimental Bridge Scour Mitigation at Selected Bridges in Utah, 2003-05
}

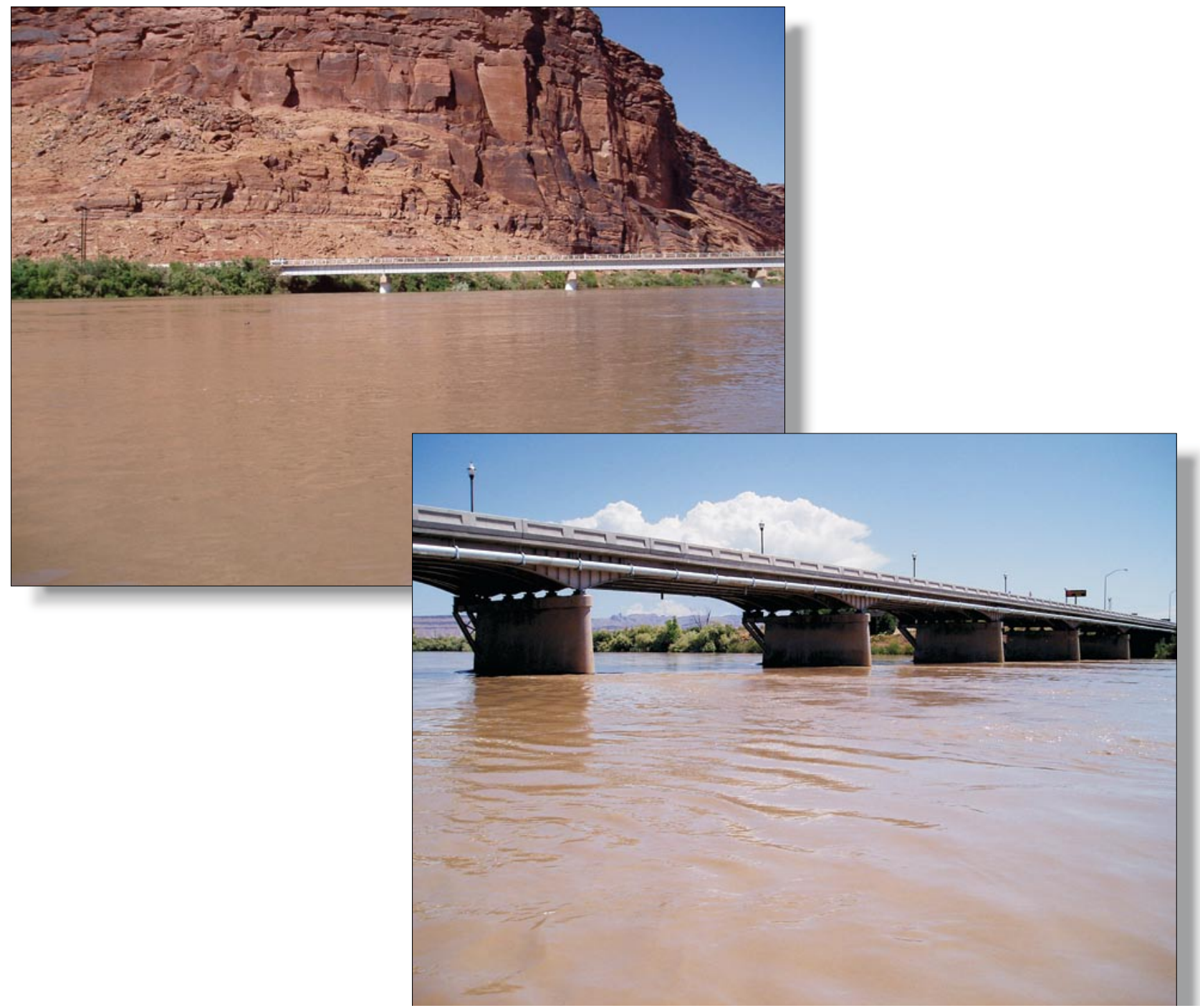

Scientific Investigations Report 2006-5033

U.S. Department of the Interior

U.S. Geological Survey 
Cover: Top left, Upstream view of Colorado River Bridge at State Road 191, May 2005

(Photograph by T.A. Kenney). Bottom right, Upstream view of Green River Bridge at State Road 19, May 2003 (Photograph by T.A. Kenney). 


\section{Hydraulic and Geomorphic Monitoring of Experimental Bridge Scour Mitigation at Selected Bridges in Utah, 2003-05}

By Terry A. Kenney and Tim S. McKinney

Scientific Investigations Report 2006-5033

Prepared in cooperation with the

UTAH DEPARTMENT OF TRANSPORTATION

U.S. Department of the Interior

U.S. Geological Survey 


\section{U.S. Department of the Interior \\ Gale A. Norton, Secretary}

\section{U.S. Geological Survey \\ P. Patrick Leahy, Acting Director}

Salt Lake City, 2006

For additional information write to:

U.S. Geological Survey

Director, USGS Utah Water Science Center

2329 W. Orton Circle

Salt Lake City, UT 84119-2047

Email: GS-W-UTpublic-info@usgs.gov

URL: http://ut.water.usgs.gov/

For more information about the USGS and its products:

Telephone: 1-888-ASK-USGS

World Wide Web: http://www.usgs.gov/

Any use of trade, firm, or product names is for descriptive purposes only and does not imply endorsement by the U.S. Government

Although this report is in the public domain, permission must be secured from the individual copyright owners to reproduce any copyrighted materials contained within this report. 


\section{Contents}

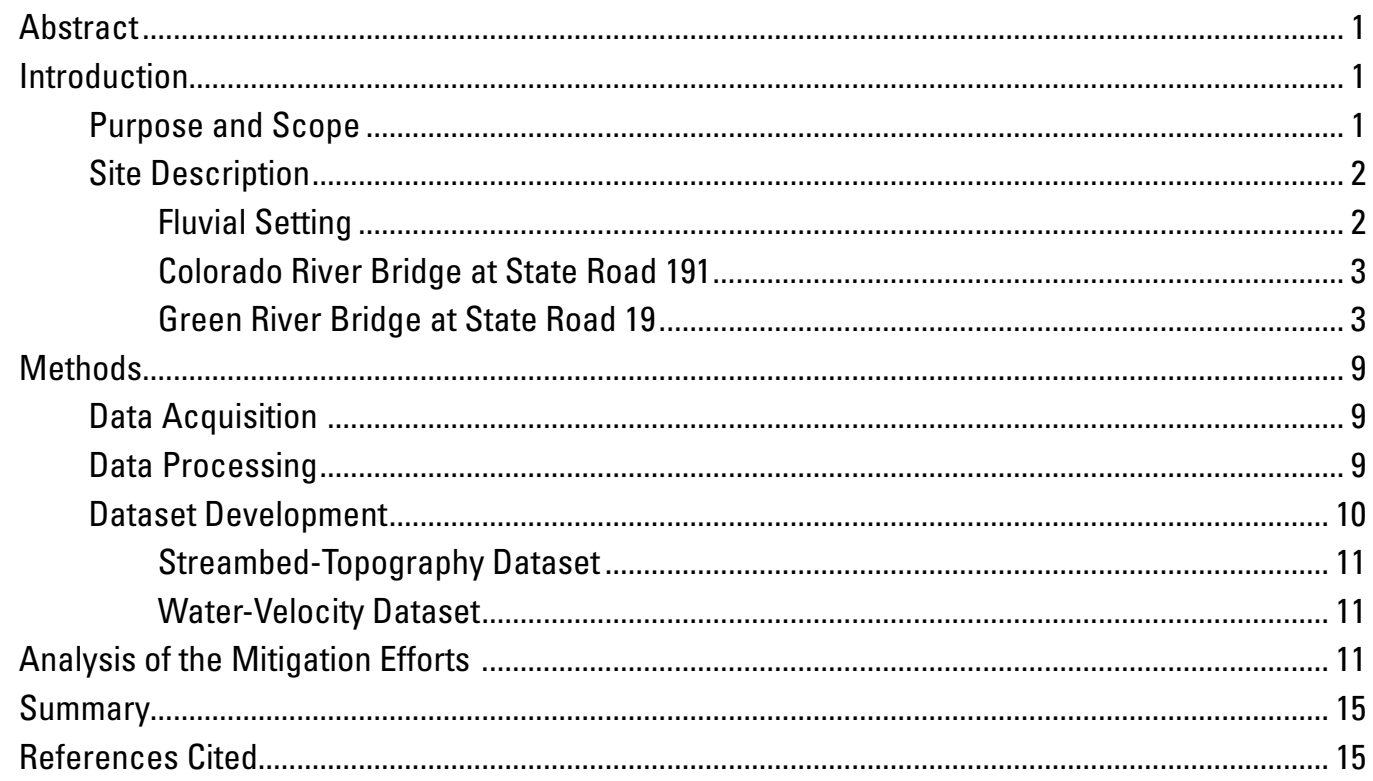

\section{Figures}

Figure 1. Location of Colorado River Bridge at State Road 191 and the Green River Bridge at State Road 19 study areas, Utah.

Figure 2. (A) Single A-Jack, (B) A-Jacks module installed at Green River Bridge at State Road 19), and (C) a portion of the A-Jacks matrix at Green River Bridge at State Road 19 during low flow conditions, October 2003

Figure 3. Schematic design for A-Jacks scour countermeasures for the Colorado River Bridge at State Road 191

Figure 4. Schematic design for A-Jacks scour countermeasures for the Green River Bridge at State Road 19

Figure 5. (A) Colorado River inlet to Moab Valley, Utah, 1905. Note lack of tamarisk presence;

(B) Colorado River inlet to Moab Valley, Utah, 1998. Photograph modified to show Tamarisk presence along river banks

Figure 7. Downstream view of the Colorado River Bridge at State Road 191, 2005 ......................... 7

Figure 6. Construction of the Colorado River Bridge at State Road 191, mid 1950s ............................ 7

Figure 8. Arial photograph of Green River Bridge at State Road 19, 2004........................................ 8

Figure 9. Schematic of how a unique location is assigned to discreet depths measured by each acoustic Doppler current profiler beam

Figure 10. Three-dimensional simulated view of Colorado River Bridge at State Road 191 developed from interpolated elevation dataset of 2005 combined with a digital elevation model

Figure 11. Plan views of interpolated elevation datasets for Colorado River Bridge at State Road 191, 2003 to 2005

Figure 12. Zoomed in plan views of interpolated elevation datasets for Green River Bridge at State Road 19, 2003-05. 


\section{Tables}

Table 1. Water-surface elevations and discharges observed during each bridge survey 9

\section{Appendixes}

Appendix A. Unorganized streambed-topography datasets ................................................................ 16

Appendix B. Unorganized vertically averaged water-velocity vector datasets........................................ 16

Appendix C. Organized interpolated streambed-topography datasets ..................................................... 16

Appendix D. Organized interpolated water-velocity vector datasets ..................................................... 16

\section{Conversion Factors and Datums}

\begin{tabular}{lll}
\hline \multicolumn{1}{c}{ Multiply } & \multicolumn{1}{c}{ By } & \multicolumn{1}{c}{ To obtain } \\
\hline foot $(\mathrm{ft})$ & 0.3048 & meter $(\mathrm{m})$ \\
square mile $\left(\mathrm{mi}^{2}\right)$ & 2.590 & square kilometer $\left(\mathrm{km}^{2}\right)$ \\
foot per second $(\mathrm{ft} / \mathrm{s})$ & 0.3048 & meter per second $(\mathrm{m} / \mathrm{s})$ \\
cubic foot per second $\left(\mathrm{ft}^{3} / \mathrm{s}\right)$ & 0.02832 & cubic meter per second $\left(\mathrm{m}^{3} / \mathrm{s}\right)$ \\
\hline
\end{tabular}

Horizontal coordinate information is referenced to the North American Datum of 1983 (NAD 83).

Vertical coordinate information is referenced to the North American Vertical Datum of 1988 (NAVD 1988). 


\title{
Hydraulic and Geomorphic Monitoring of Experimental Bridge Scour Mitigation at Selected Bridges in Utah, 2003-05
}

\author{
By Terry A. Kenney and Tim S. McKinney
}

\section{Abstract}

Unique bridge scour mitigation designs using concrete A-Jacks were developed by the Utah Department of Transportation and installed at the Colorado River Bridge at State Road 191 and the Green River Bridge at State Road 19. The U.S. Geological Survey monitored stream reaches at these sites by collecting streambed-topography and water-velocity data from 2003 through 2005. These data were acquired annually from a moving boat with an acoustic Doppler current profiler and a differential global positioning system. Raw unordered data were processed and readied for interpolation into organized datasets with DopplerMacros, a set of computer programs. Processed streambed topography data were geostatistically interpolated by using Ordinary Kriging, and inverse distance weighting interpolation was used in the development of the two-dimensional velocity datasets. These organized datasets of topography and velocity were developed for each survey of the two bridge sites. A comparison of the riverbed topography data for each survey was done. An increase in bed elevation related to the installation of the A-Jacks scour countermeasures is evident at the Colorado River Bridge at State Road 191. The three topographic datasets acquired after the installation at the Green River Bridge at State Road 19 show few changes.

\section{Introduction}

Studies done by the Utah Department of Transportation (UDOT) determined that the Colorado River Bridge at State Road 191 and the Green River Bridge at State Road 19 (fig. 1) are scour critical. Both bridges span highly mobile gravelbed rivers dominated by snowmelt-runoff discharge events. Mitigating the scour problems at each of these sites in both an environmental and cost-effective manner is a priority of UDOT.

UDOT engineers designed plans using concrete A-Jacks scour countermeasures for the scour-susceptible areas of the two bridges. In the UDOT design, 36 single A-Jacks structures are banded together to form modules that are placed in a matrix on the streambed (fig. 2). The design of these modules has three benefits: they armor the streambed, they dissipate energy near the substrate around the piers, and they promote sediment deposition onto and between the A-Jacks modules. Conceptually, this design is self-propagating because it inhibits scour while increasing its armoring capabilities (Michael Fazio and Denis Stuhff, Utah Department of Transportation, oral commun., 2003).

The UDOT designs are unique and experimental for several reasons. At the Colorado River Bridge, two different matrices were installed concentrically around two piers (fig. 3 ). Deployment of the modules at the Green River Bridge at State Road 19 is such that a single matrix occupies the entire area from the right abutment past the right-most bridge pier (fig. 4). At this site, no geo-tech fabric is installed underneath the modules. Installations at both sites were made with only minor channel-bed modifications. Installation of the A-Jacks scour countermeasures was completed in February 2003 at the Green River Bridge, and March 2004 at the Colorado River Bridge. Case studies on these types of deployments in steep, mobile gravel-bed river environments have not been done before this study. The U.S. Geological Survey (USGS), in cooperation with UDOT, monitored streambed elevations and water velocities associated with the A-Jacks deployments at the Colorado River Bridge at State Road 191, and the Green River Bridge at State Road 19, from 2003 through 2005.

\section{Purpose and Scope}

This report documents the method and technologies used in monitoring the unique deployment of the A-Jacks bridge scour countermeasures at the Colorado River Bridge at State Road 191, and the Green River Bridge at State Road 19. The techniques used in acquiring the hydraulic and geomorphic data are outlined. This report describes how the raw data were processed and then interpolated into organized datasets of streambed elevation and vertically averaged water-velocity vectors. This report is not a direct assessment of the bridge scour mitigation at these sites in Utah. The data presented here represent an initial baseline condition of the deployed A-Jacks that can be used as part of a future evaluation of their performance. These data should provide valuable insight for future monitoring and hydraulic modeling, and help guide future installations. 


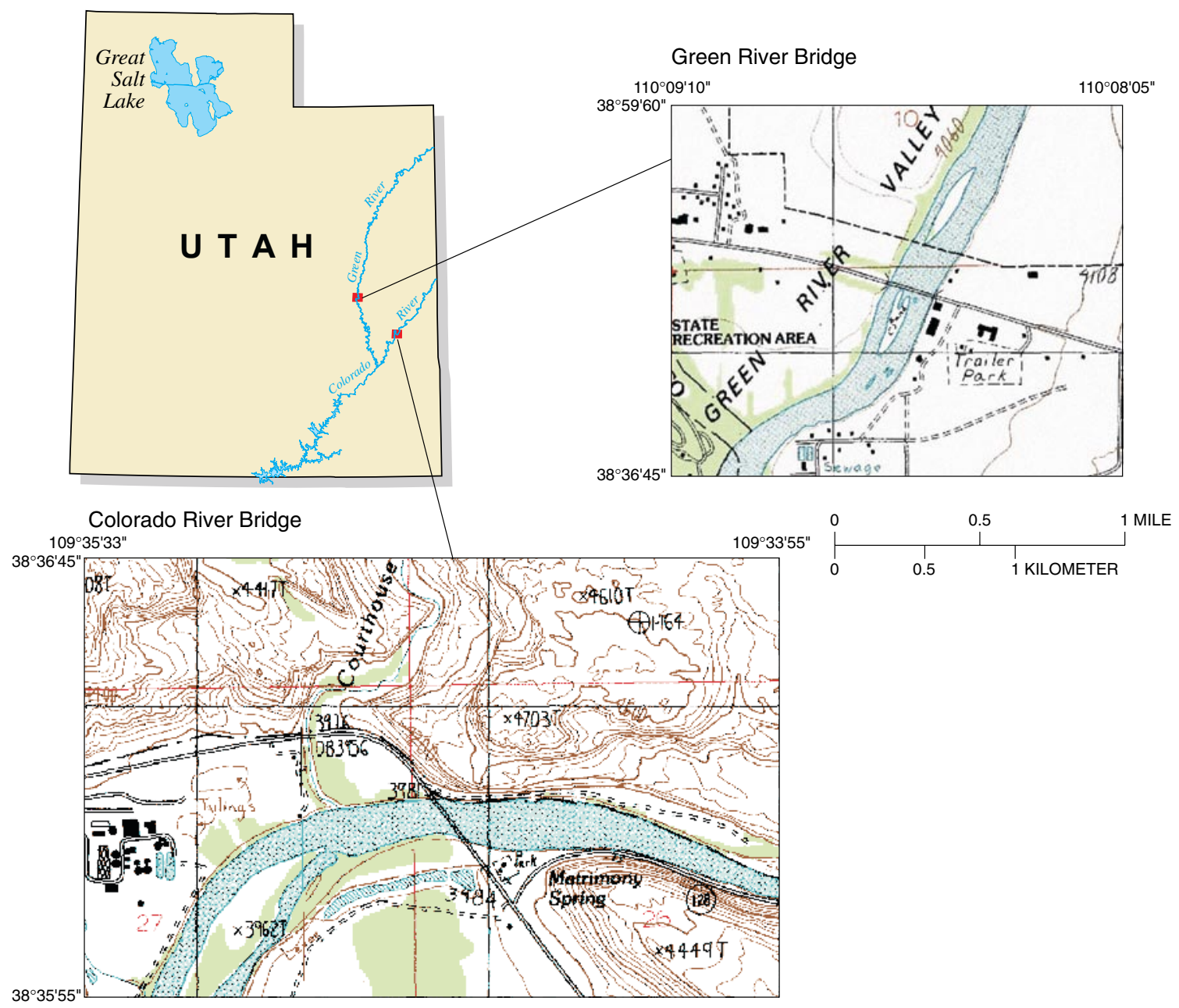

Figure 1. Location of Colorado River Bridge at State Road 191 and the Green River Bridge at State Road 19 study areas, Utah.

\section{Site Description}

\section{Fluvial Setting}

The Colorado and Green Rivers in Utah are snowmelt dominated systems with annual peak discharges typically occurring in late spring. These flow events generally begin in May, peak in the beginning of June, and recede to baseflow conditions by July. Bridge structures located within these types of fluvial environments experience sustained large magnitude flows.

Both the Colorado River Bridge at State Road 191 and the Green River Bridge at State Road 19 were constructed in the middle part of the $20^{\text {th }}$ century. This same time period is associated with the commencement of extensive flow regulation and the proliferation of tamarisk (Tamarix chinensis) throughout the upper Colorado and Green River drainage basins. Although first introduced to the region in the 1800s, around 1940 the invasive riparian shrub, tamarisk, appeared along the Colorado River near Moab, Utah, and the Green River near Green River, Utah. The spread of tamarisk throughout the Colorado Plateau has lead to the most dramatic change in the fluvial landscape during the past century (Graf, 1978). By densely colonizing much of the riverbanks and many channel islands, tamarisk has stabilized channel margins by anchoring the soil and dissipating water-velocity energy. This stabilization together with flow regulation has caused historically wide, shallow rivers to narrow and become incised. This change is apparent in repeat photography of Moab Valley taken in 1905 and 1998 (fig. 5). Evidence of this type of channel evolution, which is associated with some of the scour problems being mitigated, can be seen at both bridges. 

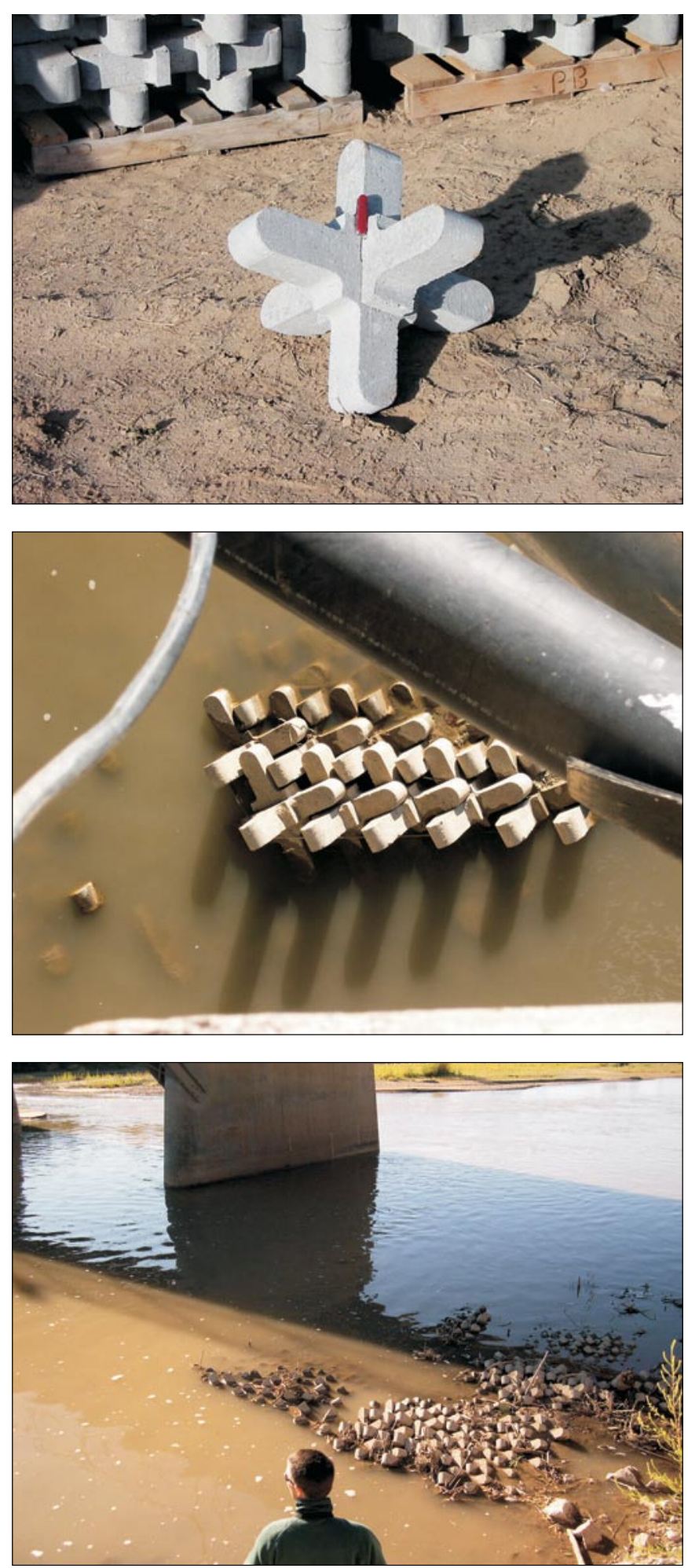

Figure 2. (A) Single A-Jack (Photograph by T.A. Kenney), (B) A-Jacks module installed at Green River Bridge at State Road 19 (Photograph by T.L. Ularich), and (C) a portion of the A-Jacks matrix at Green River Bridge at State Road 19 during low flow conditions, October 2003 (Photograph by T.L. Ularich).

\section{Colorado River Bridge at State Road 191}

The Colorado River drains more than $24,500 \mathrm{mi}^{2}$ of Utah and Colorado upstream from State Road 191. Upstream from the bridge, the Colorado River is confined laterally by large consolidated sedimentary deposits of Jurrassic and Cretaceous age common to the Colorado Plateau (Pitlick and Cress, 2002). The bridge at State Road 191 is located at the entrance to Moab Valley, Utah, one of the few locations within the Colorado Plateau where the river is not confined laterally by bedrock. The average river slope near the bridge is 0.0002 $\mathrm{ft} / \mathrm{ft}$, and bed materials range from coarse gravels to silts. Average annual peak discharge at USGS streamflow-gaging station 09180500, Colorado River near Cisco, Utah, for the 86 -year period of record is $36,300 \mathrm{ft}^{3} / \mathrm{s}$. Since 1950 , about the beginning of upstream flow regulation, average annual peak discharge is $29,400 \mathrm{ft}^{3} / \mathrm{s}$ (Kenney, 2005).

Nearly all discharges at the Colorado River Bridge at State Road 191 are currently conveyed through only four of the eight spans of the bridge, which has in part lead to the scour identified by UDOT at pier numbers 6 and 7 . An historical photograph taken at low flow conditions during the construction of the Colorado River Bridge at State Road 191 shows evidence that recent streamflow, likely the spring runoff, occupied the left side of the river channel at pier numbers 3,4 , and 5 (fig. 6). Note the lack of tamarisk on the left bank of the river near the bridge. Tamarisk can be seen in this same area in a photo taken in 2005 (fig. 7).

\section{Green River Bridge at State Road 19}

The contributing drainage basin of the Green River above State Road 19 is roughly 41,000 $\mathrm{mi}^{2}$. The Green River near Green River, Utah, occupies a shale and sandstone dominated alluvial plateau. Average river slope at the State Road 19 Bridge is $0.0004 \mathrm{ft} / \mathrm{ft}$ and bed materials consist of moderately sized gravels, sands, and silts. Average annual peak discharge at USGS streamflow-gaging station 09315000, Green River at Green River, Utah, for the 104-year period of record is 28,400 $\mathrm{ft}^{3} / \mathrm{s}$. Since 1962, when Flaming Gorge Reservoir was completed, average annual peak discharge is $22,000 \mathrm{ft}^{3} / \mathrm{s}$.

The stabilization by tamarisk of a prominent mid-channel island upstream of the Green River Bridge at State Road 19 has lead to an uneven distribution of streamflow through the seven bridge spans. Sediment deposition on the downstream side of the island has propagated through the reach containing the bridge (fig. 8). Flow has become incised and concentrated on the right edge of the river through the two bridge spans separated by pier number 8 . 

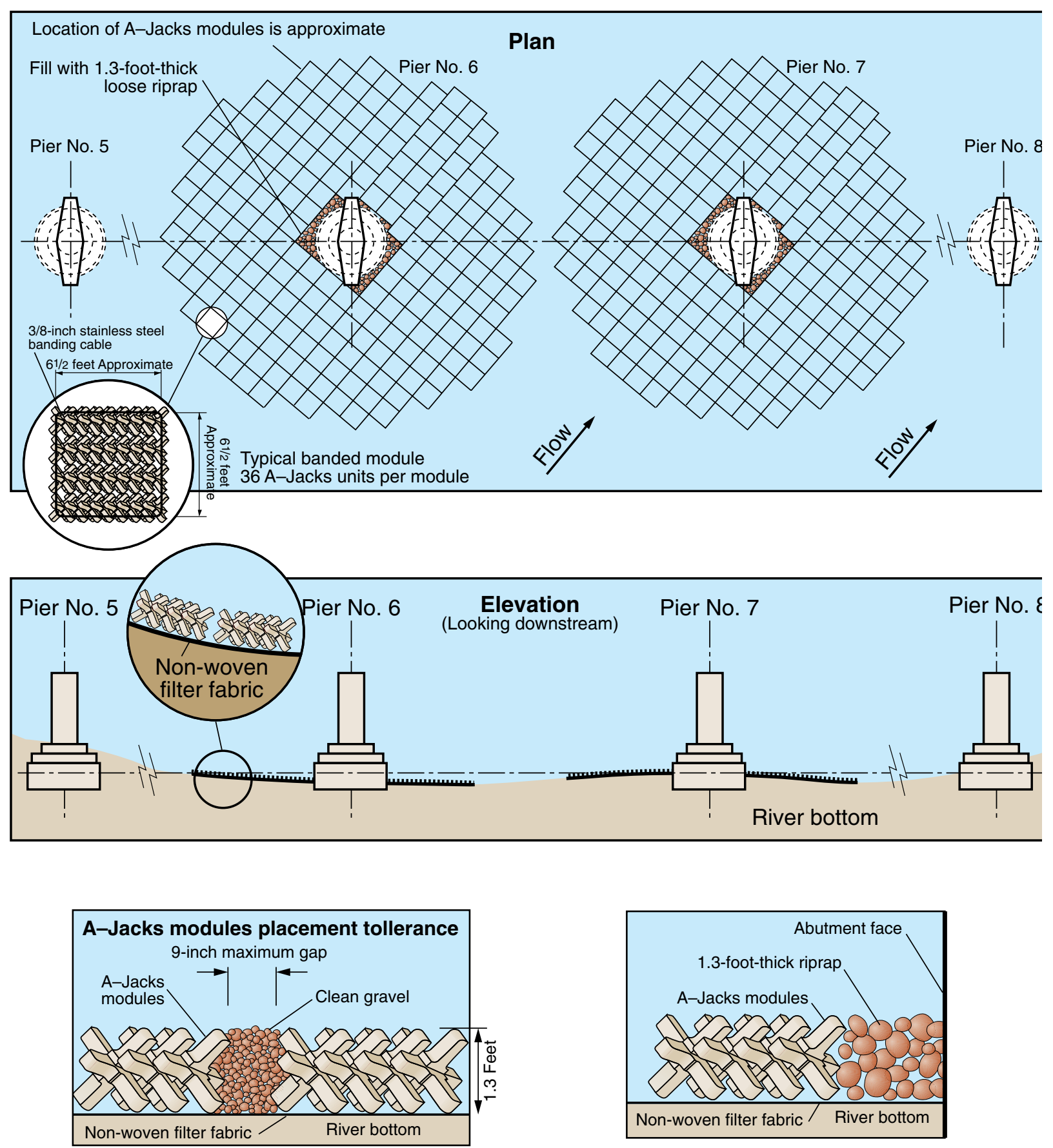

Figure 3. Schematic design for A-Jacks scour countermeasures for the Colorado River Bridge at State Road 191. 

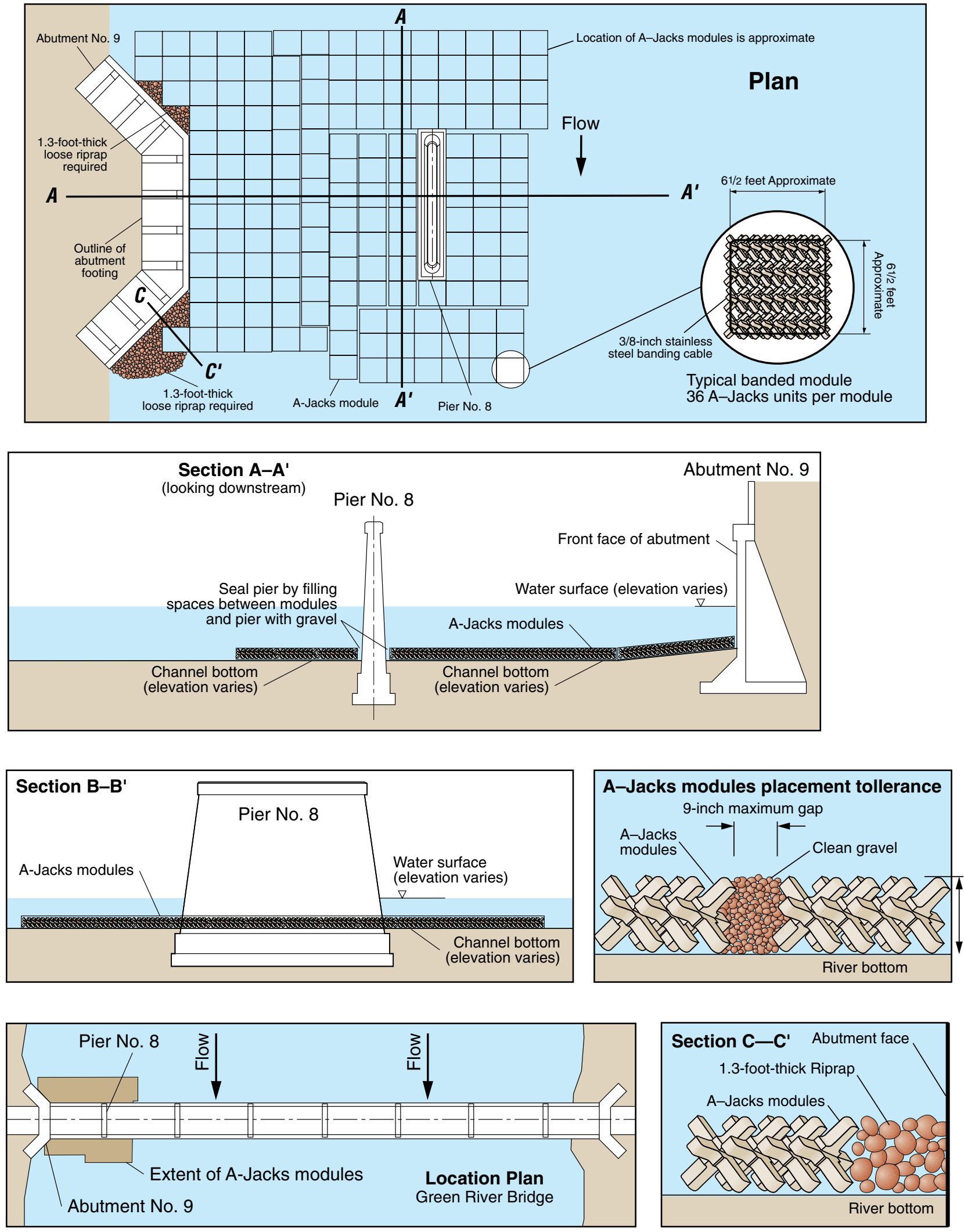

Figure 4. Schematic design for A-Jacks scour countermeasures for the Green River Bridge at State Road 19. 

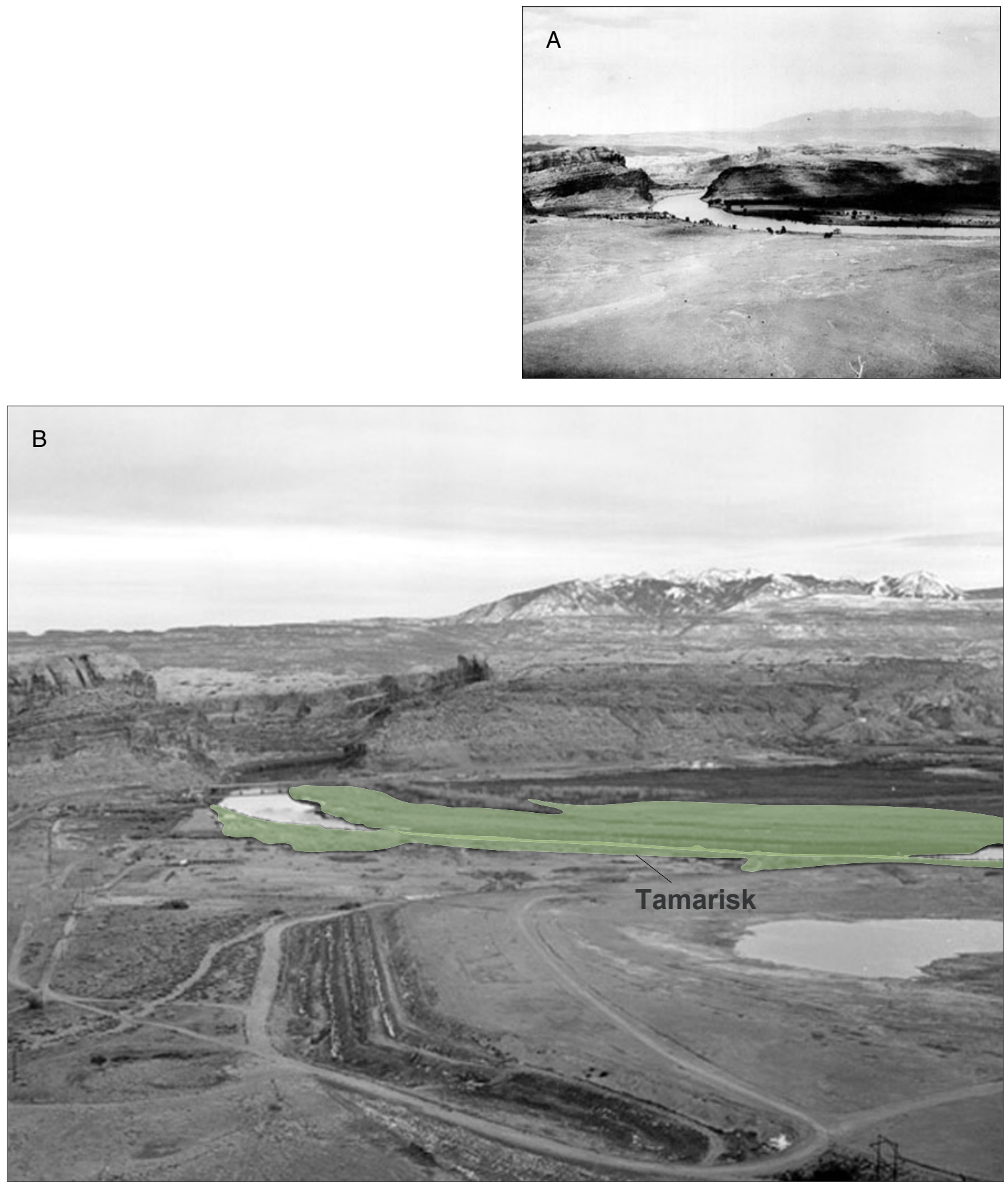

Figure 5. (A) Colorado River inlet to Moab Valley, Utah, 1905. Note lack of tamarisk presence (Photograph by C.C. Whitman); (B) Colorado River inlet to Moab Valley, Utah, 1998. Photo modified to show Tamarisk presence along river banks (Modified from Kenney, 2005). 


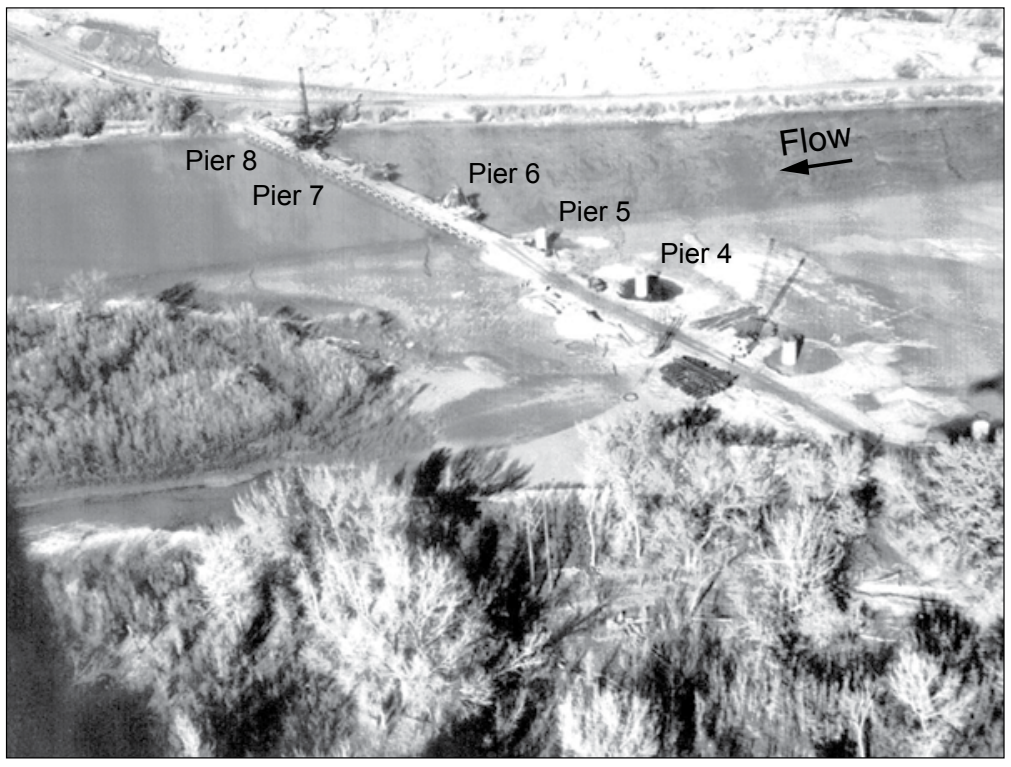

Figure 6. Construction of the Colorado River Bridge at State Road 191, mid 1950s.

(Photograph by D.E. Byrd, courtesy of Moab Times-Independent)

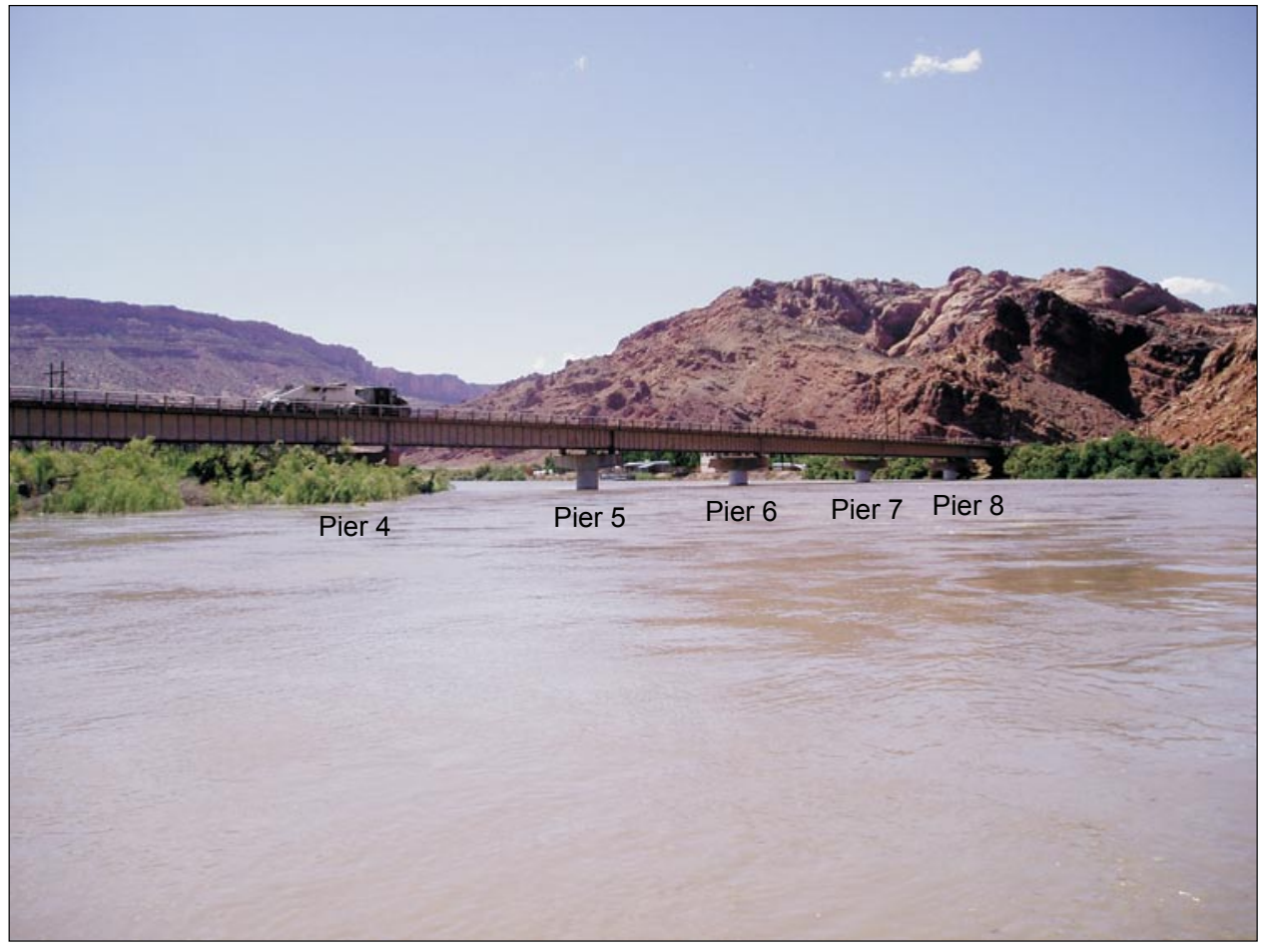

Figure 7. Downstream view of the Colorado River Bridge at State Road 191, 2005.

(Photograph by T.A. Kenney) 


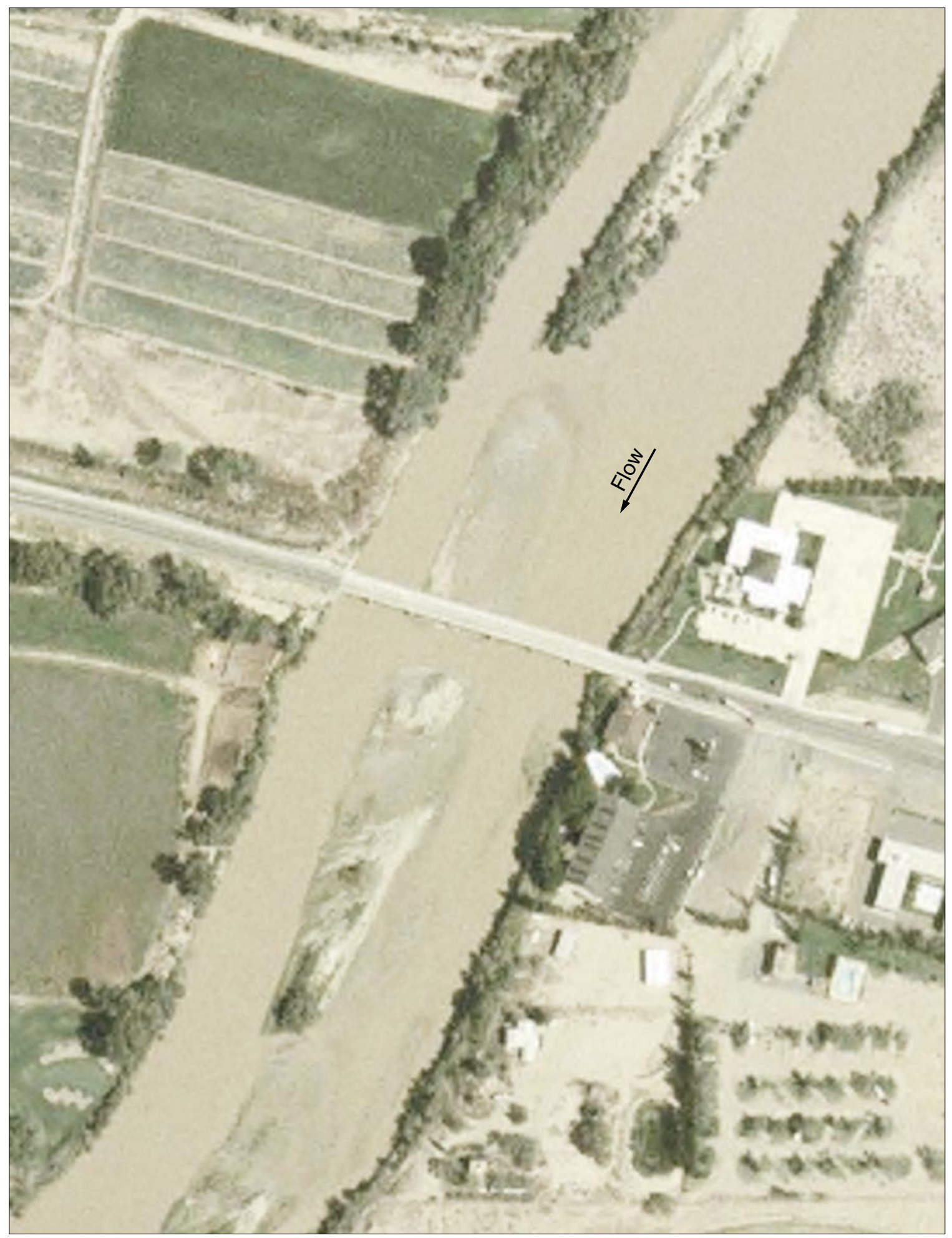

Figure 8. Arial photograph of Green River Bridge at State Road 19, 2004.

Sediment deposition on the downstream end of channel bar extending through the bridge can be seen. 


\section{Methods}

\section{Data Acquisition}

Data-collection surveys were done during the spring snowmelt runoff period at the Colorado River Bridge and the Green River Bridge from 2003 through 2005. Discharges and water-surface elevations measured during the surveys, along with the annual peak discharge recorded at the nearest USGS streamflow-gaging stations; 09180500 Colorado River near Cisco, Utah, and 09315000 Green River at Green River, Utah, are contained in table 1 .

A unique method coupled with advanced technology was used to comprehensively monitor the performance of the scour mitigation designs at the selected bridges in Utah. Data most critical to an assessment of the scour countermeasures includes channel geometry and water velocities at varying discharges. By using an acoustic Doppler current profiler (ADCP) interfaced with a differential global positioning system (DGPS) deployed from a moving boat, velocities and depths were simultaneously collected and spatially registered throughout each study reach.

The ADCP used has four acoustic transducers each oriented 20 degrees from the center of the ADCP. Each of these beams measures total water depth and a specified velocity component throughout most of the water column. With the orientation of the acoustic beams, the depths measured

Table 1. Water-surface elevations and discharges observed during each bridge survey

\begin{tabular}{lccc}
\hline Date & $\begin{array}{c}\text { Water- } \\
\text { surface } \\
\text { elevation } \\
\text { at bridge } \\
\text { (feet) }\end{array}$ & $\begin{array}{c}\text { Discharge } \\
\text { (cubic feet } \\
\text { per second) }\end{array}$ & $\begin{array}{c}\text { Annual peak } \\
\text { discharge at } \\
\text { USGS stream- } \\
\text { flow-gaging } \\
\text { station }\end{array}$ \\
(cubic feet per \\
second)
\end{tabular}

by the ADCP are accepted to be accurate to within 1 percent of the true depth (R.D. Instruments, oral commun., 2003). The DGPS is mounted directly above the ADCP, logging its center position. ADCPs measure water velocities by using the principle of the Doppler Effect. Velocities are resolved by computing the shift in frequency of sound waves returned by moving particles within the water column. By employing this principle and collecting data with multiple acoustic beams, ADCPs are capable of measuring three-dimensional water velocities throughout most of the water column. Due to limitations associated with acoustic technology such as the required submergence of the transducers, transducer noise, and acoustic side lobe interference, small portions of water column near the water surface and close to the channel bed are unable to be sampled. The ADCP has an internal compass, which, when properly calibrated and assigned the proper magnetic variation/declination, allows velocity vector components to be collected in a true world coordinate system. For an in-depth discussion on the technical operation of ADCPs refer to Simpson (2001).

For this study, measured water velocities were calculated by using the bottom track feature of the ADCP. This feature operates under the assumption that the channel bed is stationary. Bottom tracking treats any shift in frequency associated with the streambed to the velocity of the ADCP, often termed the boat velocity. In the presence of a moving bed in the streamwise direction, measured water velocities are negatively biased. Use of a DGPS to obtain the boat velocity can alleviate this bias. However, due to the corruption of DGPS signals near structures, such as bridges, and the processing software used, water-velocity data presented in this report were computed by using bottom tracking and as a result may be less than the true water velocity by a factor equal to the streamwise bed velocity. Comparable DGPS and bottom-tracking data acquired at the Colorado River bridge in 2005 indicates that the true water velocity at a discharge of $28,000 \mathrm{ft}^{3} / \mathrm{s}$ may be as much as $0.40 \mathrm{ft} / \mathrm{s}$ greater than that presented in this report. Data from the largest observed discharge at the Green River Bridge, $27,000 \mathrm{ft}^{3} / \mathrm{s}$, indicates that the true water velocity may be as much as $0.30 \mathrm{ft} / \mathrm{s}$ greater than that presented in this report. The DGPS was used to spatially register all measured depths and velocities. Corrupted location DGPS data was manually adjusted using the logged bottom-tracking vector coordinates.

A digital data-collection grid was developed for each bridge site and utilized for the 2004 and 2005 data-collection surveys. This grid was navigated in realtime using a handheld GPS interfaced with a personal digital assistant (PDA).

\section{Data Processing}

Field data acquired with the ADCP is unordered, in that it is comprised of velocities and depths that are collected wherever the boat is driven. Raw data from the channel surveys were exported from the data-collection software in an ASCII 
format and processed with DopplerMacros, a series of Visual Basic Macros (Microsoft Corporation, Redmond, Wash., written commun., 2000) developed by Dinehart (2003). These macros perform a number of tasks to ready the data for display and/or interpolation.

Positional data collected by the DGPS is defined in the geographic coordinate system (GCS) angular measures of degrees of longitude and latitude referenced to the World Geodetic Coordinate System of 1984 (WGS 84). DopplerMacros prepares these geographic data for conversion into Universal Trans-Mercator (UTM), North American Datum of 1983 (NAD 83), Zone 12 system by Corpscon (version 6.0.1, U.S. Army Corps of Engineers, written commun., 2004). Following conversion, these data are then re-inserted into the data files by DopplerMacros.

The macros separate the discreet depths measured by each of the ADCP's four beams. DopplerMacros computes the horizontal offset from the logged ADCP position by solving the trigonometric relation associated with the 20-degreefrom-center beam and the measured depth. This offset is then added to the logged horizontal position, in proper relation to the internal compass reading of the ADCP, and a unique location of each measured depth is assigned (fig. 9). The computer programs subtract the measured depths from user input water-surface elevations, changing the dataset from depths below water surface to streambed elevations. A single watersurface elevation, measured at each bridge structure, was input for each of the surveys conducted. Water-surface elevations at the Green River Bridge at State Road 19 were referenced to an arbitrary vertical datum of 100 feet assigned to the top of the bridge deck barrier, and water-surface elevations at the Colorado River Bridge at State Road 191 were referenced to a surveyed bridge deck elevation of 3,984.37 feet. The processed streambed elevation datasets are contained in appendix A; however, the river slope is not represented in this dataset.

From the raw data files, DopplerMacros extracts the true world water velocity-vector components and assigns them to the geographic position of the ADCP. To meet the objective of developing a two-dimensional dataset of water-velocity vectors, the measured three-dimensional velocity vectors were vertically averaged. The vertically averaged velocity vector datasets for each survey are contained in appendix B.

\section{Dataset Development}

The primary objectives of this study were the development of organized datasets representing the topography of the riverbed, and the two-dimensional distribution of water velocities observed during each survey. To achieve these objectives, the processed data were interpolated by using different methods and computer software. The procedures used in the development of the interpolated datasets are outlined below.

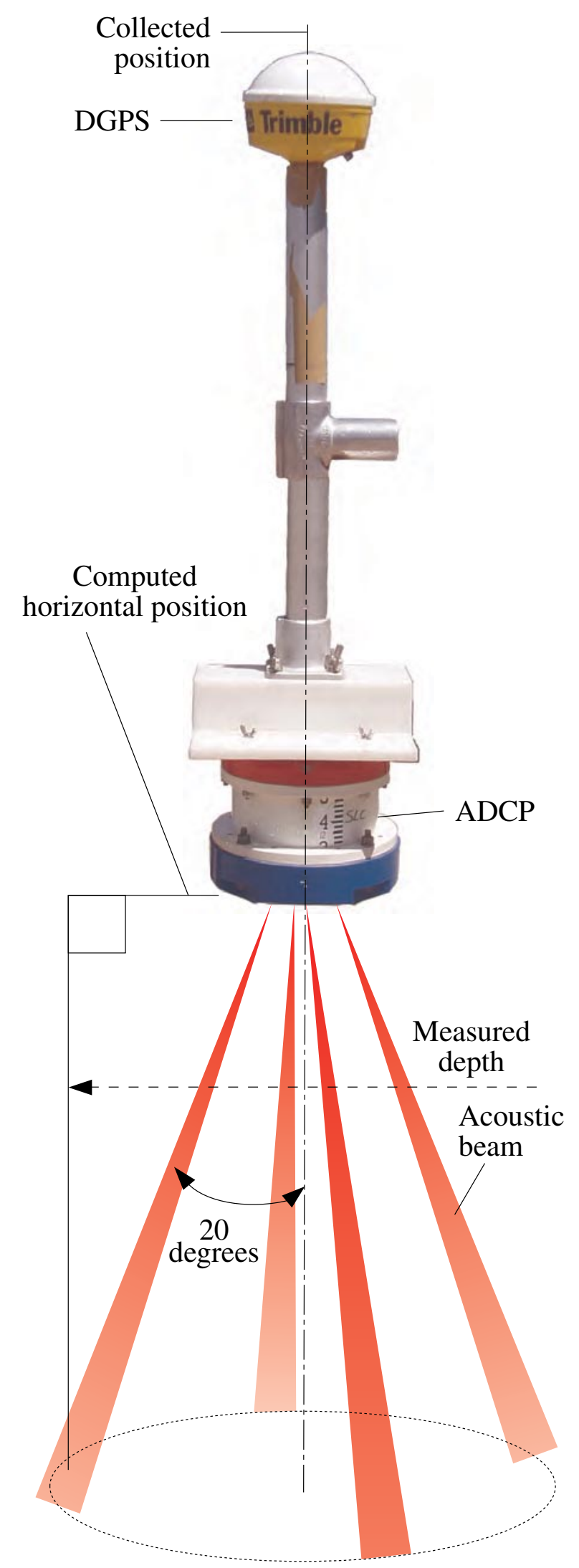

Figure 9. Schematic of how a unique location is assigned to discreet depths measured by each acoustic Doppler current profiler beam. 


\section{Streambed-Topography Dataset}

Processed elevation values were imported into a Geographic Information System (GIS) and geostatistically interpolated to create continuous surfaces. Geostatistical interpolation uses both mathematics and statistics to create a predicted surface from sampled locations and provides a measure of uncertainty for that surface. Comparisons of error or uncertainty from differing geostatistical interpolation techniques allows for an investigation of the best representation of the sampled data (Johnston and others, 2001).

For this investigation, Ordinary Kriging (OK), a geostatistical interpolation technique, was chosen. Kriging is a rigorous approach that uses the arrangement, correlation, and distance between observed data points to determine weighting. Kriging uses the semivariogram to explain the spatial autocorrelation of the sampled phenomenon. OK is modeled with spherical, circular, exponential, Gaussian, or linear functions to fit a curve of least-squares to the variance in the semivariogram and is best suited for data with no trend (Johnston and others, 2001).

To prepare the data for interpolation, a spreadsheet of sampled easting, northing, and elevation values was saved to dbase IV file format and imported to ArcGIS (version 9, Environmental Systems Research Institute (ESRI), San Diego, Calif., written commun., 2004). Once in ArcGIS, the data were converted to an ESRI shapefile and added to Geostatistical Analyst, an ESRI extension. OK parameters were defined and a predicted streambed surface was created. This predicted surface was saved to a grid of continuous regular 1 -meter cells of elevation values. In using a single referenced water-surface elevation in the processing of the raw data, slope transformations had to be done on each predicted surface to best model the river topographic surface. The river slope at each bridge, assumed equal to the surveyed water-surface slope, was applied to the raster srufaces in in MayAlgebra (McCoy and others, 2001). The river slope and streamwise distance of each elevation point from the single referenced water-surface elevation determined the amount of adjustment made. Elevation points upstream were increased, and those downstream were decreased. The slope-corrected riverbed surface was re-sampled to 2-meter cell resolution and easting, northing, and elevation values for each cell were exported. A three-dimensional simulated view of the topographic dataset from 2005 at the Colorado River Bridge is shown in figure 10. The organized, interpolated streambed-topography datasets for each survey are contained in appendix C.

\section{Water-Velocity Dataset}

The spatially registered, vertically averaged water-velocity vectors were imported into the graphical software Tecplot (version 10.0, Amtec Engineering Inc., Bellevue, Wash., written commun., 2003). To more accurately interpolate water velocities near the channel margins, the streambanks were delineated from recent aerial photographs and the geographic coordinates of the streambanks were assigned velocity vector components of $0 \mathrm{ft} / \mathrm{s}$. These streambank data also were imported into Tecplot. Rectangular grids were defined for the Colorado and Green River Bridge study reaches of 2,400 and 2,500 nodes, respectively. An inverse distance interpolation algorithm, which considered the nearest 24 points, was applied to the processed vertically averaged water velocity vectors, and the delineated streambanks. The 24 nearest points were selected by using a coordinate system octant method to ensure that the points used in computing an interpolated value were distributed as evenly as possible. The organized interpolated water-velocity vector datasets for each survey are available in appendix D. Interpolated values were generated at each of the nodes defined by the rectangular grids for each survey. This method of interpolation may have caused some velocity values to be interpolated outside of the delineated streambanks. The coverage of measured velocities varies from survey to survey. Due to shallow water depths, large regions of some surveys lack velocity measurements, particularly those of the Green River in 2003 and 2004. These areas are visible in the processed vertically averaged velocity vector datasets of appendix B.

\section{Analysis of the Mitigation Efforts}

Although this report is not an assessment of the performance of the A-Jacks scour countermeasures or their deployment designs, comparison of the acquired topographic datasets allows for some preliminary analysis of the mitigation efforts. Comparison of the velocity datasets was not done because data acquisition surveys at each bridge were conducted at different discharges.

The topographic dataset acquired in 2003 at the Colorado River Bridge at State Road 191 represents the channel conditions prior to the installation of the A-Jacks scour countermeasures. Scour in the vicinity of the piers can be seen in the 2003 dataset. Following the A-Jacks installation in 2004, an increase in the channel-bed elevation near the bridge piers is evident (fig. 11). The 2004 dataset represents conditions immediately following the installation of the A-Jacks prior to any morphologic adjustments caused by peak streamflows. The 2005 dataset was acquired following some larger river discharges.

Monitoring at the Green River Bridge at State Road 19 began following the deployment of the A-Jacks. From the three datasets acquired, the topography near the Green River Bridge (fig. 12) has changed little from 2003 to 2005. More specifically, the area near pier number 8, the location of the AJacks, appears to be at the same elevation in all three datasets. 


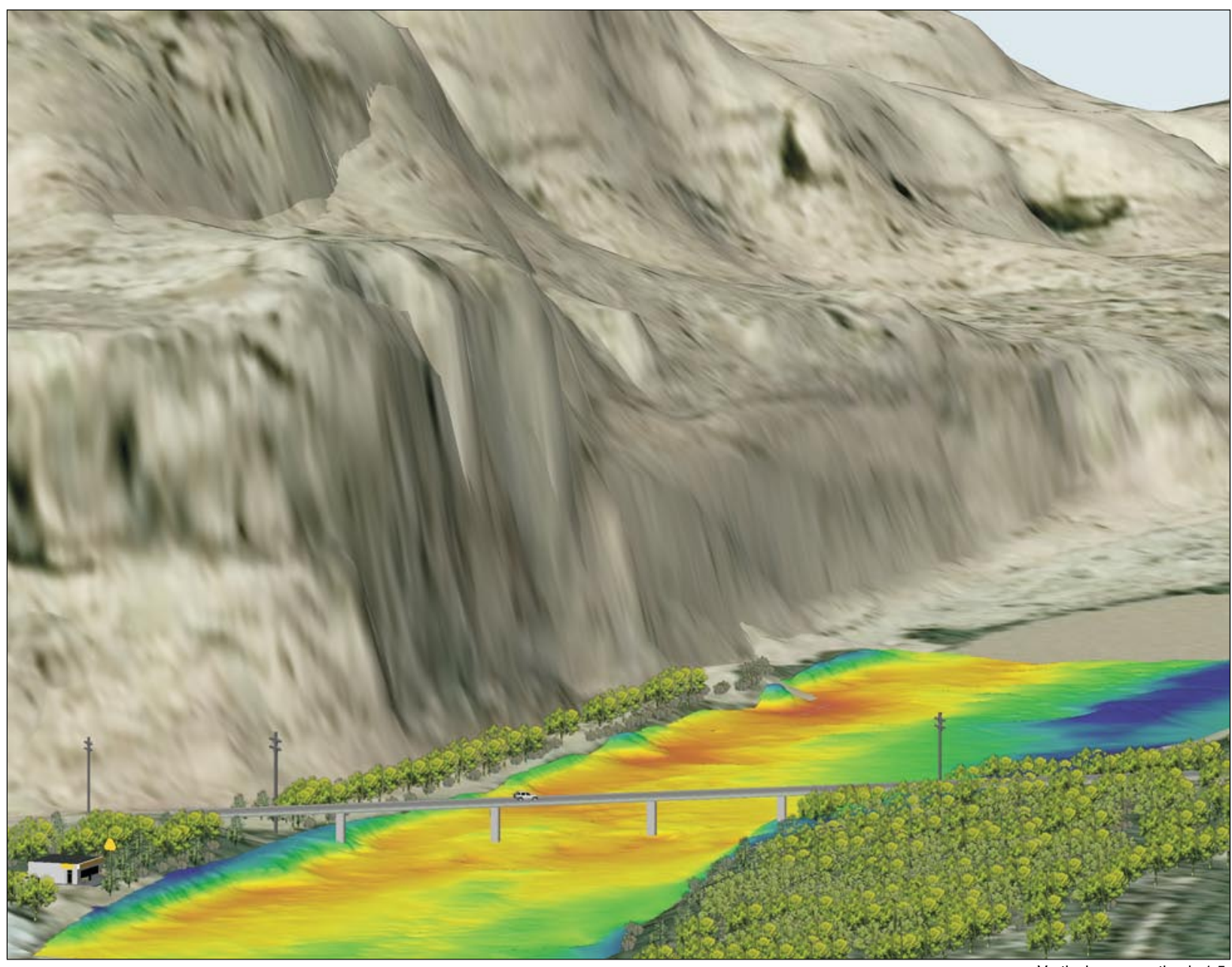

Vertical exaggeration is 1.5

EXPLANATION

Interpolated Colorado riverbed elevations, in feet

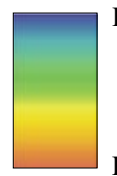

High: 3,957

Low: 3,939

Figure 10. Three-dimensional simulated view of Colorado River Bridge at State Road 191 developed from interpolated elevation dataset of 2005 combined with a digital elevation model. 

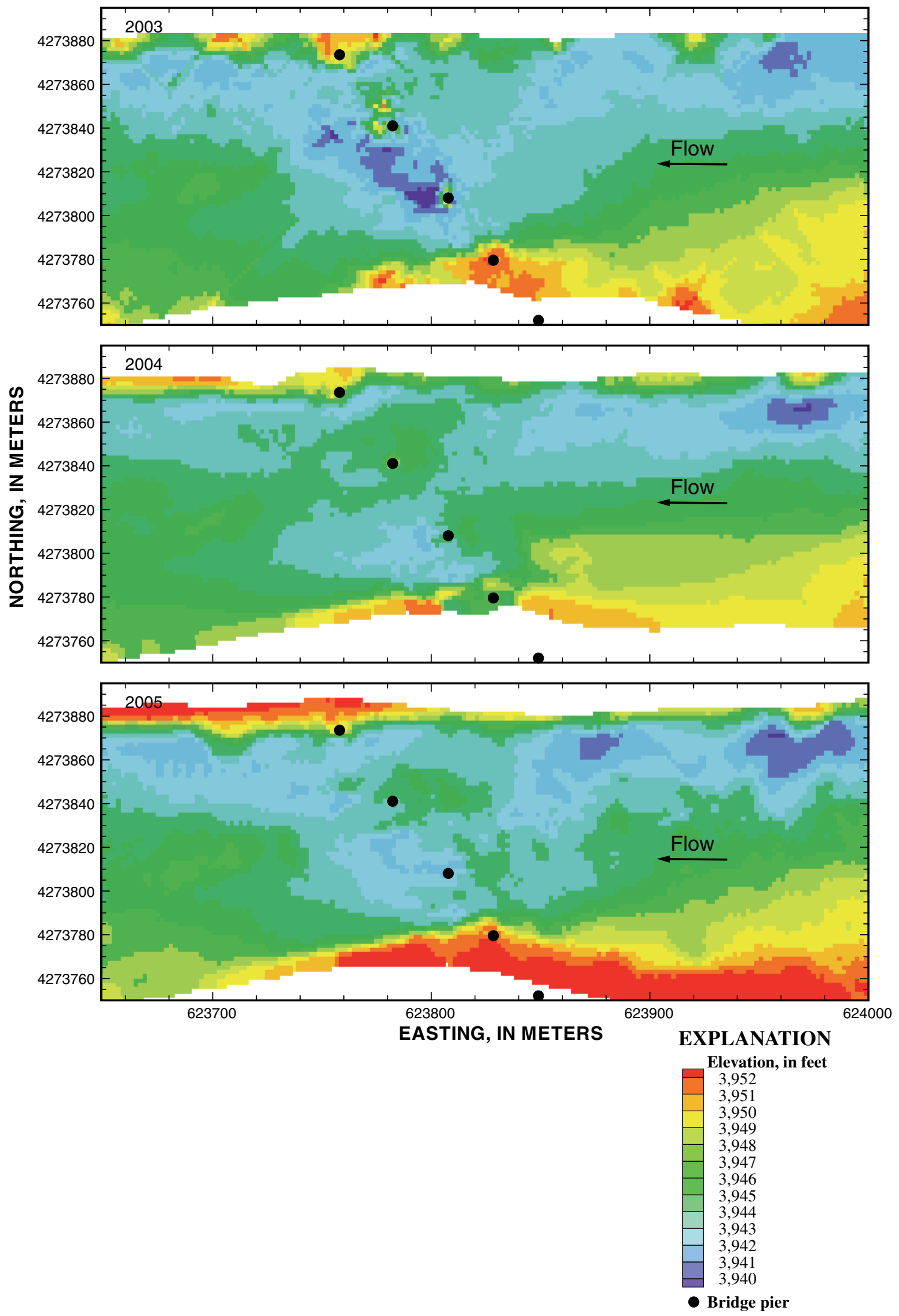

Figure 11. Plan views of interpolated elevation datasets for Colorado River Bridge at State Road 191, 2003 to 2005. 


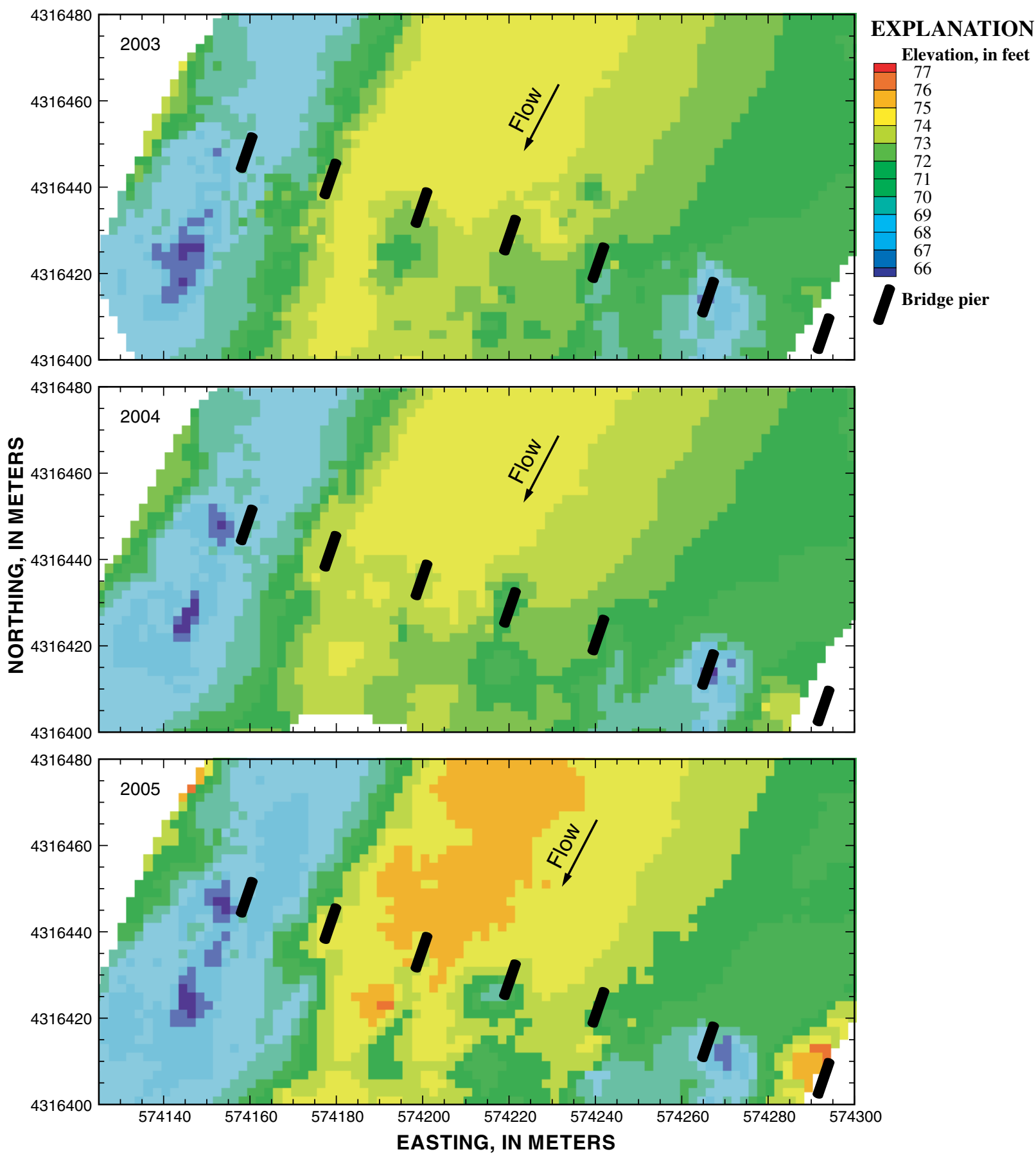

Figure 12. Zoomed in plan views of interpolated elevation datasets for Green River Bridge at State Road 19, 2003-05.

Bridge pier number 8 is the left-most pier in the figure. 


\section{Summary}

The Utah Department of Transportation developed unique and experimental bridge scour mitigation designs using concrete A-Jacks. These scour countermeasures were deployed at bridges that span highly mobile gravel-bed rivers dominated by snowmelt-runoff discharge events: the Colorado River Bridge at State Road 191 and the Green River Bridge at State Road 19. Because case studies on these types of deployments have not been done before, empirical hydraulic or geomorphic data are lacking. The USGS in cooperation with UDOT monitored the scour countermeasures from 2003 through 2005 by using a unique method coupled with advanced technology. Topographic and velocity data were acquired from a moving boat with an ADCP and DGPS coinciding with the annual snowmelt runoff period. DopplerMacros, a set of computer programs, was used to process the unorganized raw datasets. Two methods of interpolation, Ordinary Kriging for the topographic data and inverse distance for the velocity data, were used in the development of organized datasets. These datasets represent the initial hydraulic and geomorphic conditions of the study reaches following the installation of the scour countermeasures and should provide valuable information for future assessments of the mitigation strategy. Comparisons of the interpolated riverbed topography at the Colorado River Bridge show an increase in bed elevation related to the A-Jacks installations. The riverbed topography at the Green River Bridge has remained stable since the installation of the scour countermeasures. Comparisons of the velocity datasets developed during the study were not made because the data acquisition surveys were made at different discharges.

\section{References Cited}

Dinehart, R.L 2003, Spatial analysis of ADCP data in streams, in Gray, J.R., ed., Proceedings of the Federal Interagency Sediment Monitoring Instrument and Analysis Research Workshop, September 9-11, 2003, Flagstaff, Ariz.: U.S. Geological Survey Circular 1276, accessed August 5, 2005 at http://water.usgs.gov/osw/techniques/sediment/sedsurrogate2003workshop/dinehart.pdf

Graf, W.L., 1978, Fluvial adjustments to the spread of tamarisk in the Colorado Plateau region: Geological Society of America Bulletin, v. 89, p. 1491-1501.

Johnston, K., Ver Hoef, J.M., Krivoruchko, K., Lucas, N., 2001, Using ArcGIS Geostatistical Analyst: Redlands, Calif., Environmental Systems Research Institute, 300 p.

Kenney, T.A., 2005, Initial-Phase Investigation of MultiDimensional Streamflow Simulations in the Colorado River, Moab Valley, Grand County, Utah, 2004: U.S. Geological Survey Scientific Investigations Report 2005-5022, 69 p.

McCoy, J., Johnston, K., Kopp, S., Borup, B., Willison, J., 2001, Using ArcGIS Spatial Analyst: Redlands, Calif., Environmental Systems Research Institute, 232 p.

Pitlick, John, and Cress, Robert, 2002, Downstream changes in the channel geometry of a large gravel bed river: Water Resources Research, v. 38, no. 10, 12 p.

Simpson, M.R., 2001, Discharge measurements using a broadband acoustic Doppler current profiler: U.S. Geological Survey Open-File Report 01-01, 123 p. 


\section{Appendixes}

Appendix directories contain text files of the named datasets.

Appendix A. Unorganized streambed-topography datasets

Appendix B. Unorganized vertically averaged water-velocity vector datasets

Appendix C. Organized interpolated streambed-topography datasets

Appendix D. Organized interpolated water-velocity vector datasets 


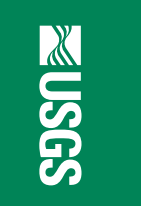

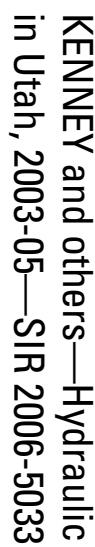

气

๑

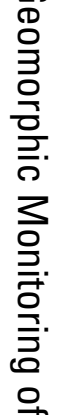

畧

을.

勇

ㅁ

등

$\infty$

@.

c

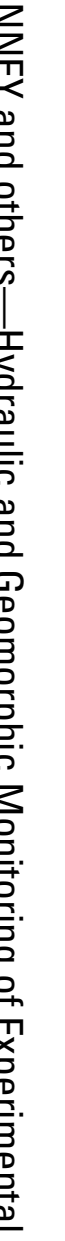

D

$\stackrel{9}{9}$

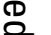

뜸 